\title{
A rule-based availability-driven cosynthesis scheme
}

\author{
Shampa Chakraverty • Anil Kumar
}

Published online: 21 November 2007

(C) Springer Science+Business Media, LLC 2007

Erratum to: Des Autom Embed Syst

DOI 10.1007/s10617-007-9005-88

In this article, Eq. 9a should read as:

$$
P_{\text {sys }}=\prod_{x} \int_{0}^{D l_{x}} p d f\left(C T\left(o_{x}\right)\right) d t
$$

This is an author correction.

The online version of the original article can be found at 10.1007/s10617-007-9005-88.

S. Chakraverty ( $\varangle)$

Faculty of Division of Computer Engineering, Netaji Subhas Institute of Technology, B3-B/52 A Jank Puri, New Delhi 110058, India

e-mail: apmahs@rediffmail.com

\section{A. Kumar}

Faculty of Technology, Delhi University, Delhi, India

e-mail: anilnbsingh@yahoo.co.in 